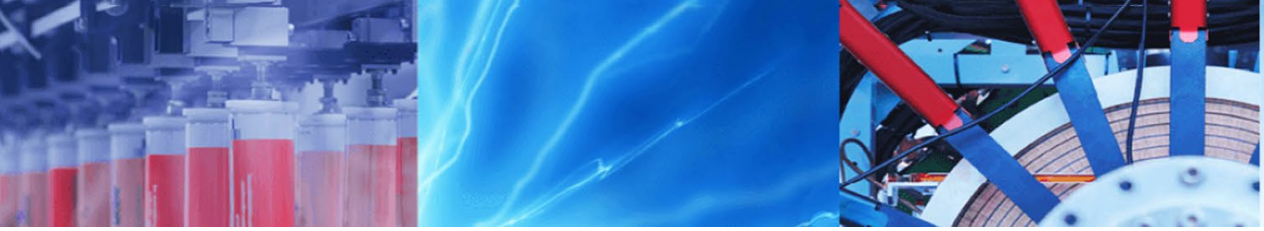

Research Article

\title{
Evaluation of curing methods and periwinkle shell concrete using response surface methodology
}

\author{
Richie I. Umasabor ${ }^{1}$
}

(c) Springer Nature Switzerland AG 2019

\begin{abstract}
The effects of periwinkle shell, curing duration and methods of curing on the compressive strength of concrete using response surface methodology were evaluated. However, the periwinkle shells were added to the concrete at $5 \%, 10 \%$ and $15 \%$ dosage by weight as partial replacement to the coarse aggregate. The concrete were cast at $0.5 \mathrm{w} / \mathrm{c} \mathrm{ratio}$ and cured between 7 days and 28 days in both water and air. Regression equations relating the blended concrete compressive strength with both the curing duration and periwinkle shell were developed. The results show that the water cured periwinkle blended concrete gave a better compressive strength than the air cured blended concrete at $5 \%$ replacement, with a $22.1 \%$ increase in the compressive strength. The adjusted $R^{2}$ of 0.9516 and 0.6838 for both water and air cured periwinkle concrete reveal that $95.16 \%$ and $68.38 \%$ of the systematic variations in the compressive strength of the periwinkle concrete is accounted for by the independent variables.
\end{abstract}

Keywords Blended concrete $\cdot$ Curing duration $\cdot$ Periwinkle shell $\cdot$ Regression

\section{Introduction}

Concrete is one of the most used materials in building and civil engineering construction work. It's a composite material comprising of a binding course e.g. cement, fine (sand) and coarse (gravel or crushed stones) aggregate [12]. Fine aggregate is sand having particle size distribution not greater than $4.75 \mathrm{~mm}$ in size while coarse aggregate is natural gravel or crushed stone usually larger than $4.75 \mathrm{~mm}$ and usually less than $16 \mathrm{~mm}$ in ordinary structure [1]. It is worth stressing that coarse aggregate usually takes about $60 \%$ of the overall self-weight of normal weight concrete, thereby determining the quantity of reinforcement required to resist forces acting on the structural member [2].

Periwinkles (Nodilittorina radiate) are small greenish blue marine snails with spiral conical shell and round aperture. Periwinkle shells are obtained from periwinkle. The hard shell periwinkles are now being considered as coarse aggregate in partial replacement for expensive, unaffordable or unavailable crushed stones.

It was reported in [5] that the main species of Tympanostomus spp. and Pachmellania spp are obtainable in some parts of Nigeria's Niger Delta, between Calabar in the east and Badagry in the west which have accumulated over the years in the southern part of the country. The periwinkle shells have been used mainly for light constructions.

Different curing methods are usually adopted to evaluate the compressive strength of concrete. The methods include; water curing (pounding or immersion, sprinkling or fogging and saturated wet covering), dry air curing (self curing), and water retaining techniques (polythene sheet, formwork protection and curing compounds).

When cement touches water, it forms a paste which coats the surface of the fine and coarse aggregates. This paste hardens through hydration process to form concrete, and their property depends upon many factors including the quality and proportions of the ingredients and the

Richie I. Umasabor, umasabor.richie@uniben.edu; princerich247@yahoo.co.uk| ${ }^{1}$ Civil Engineering Department, University of Benin, Benin City, Nigeria.

SN Applied Sciences (2019) 1:771 | https://doi.org/10.1007/s42452-019-0794-8

Received: 16 January 2019 / Accepted: 17 June 2019 / Published online: 22 June 2019 
curing environment. The most important indicator of the above properties is the water/cement ratio and the major properties of concrete influenced by water are workability, porosity, permeability and strength [8].

Factors influencing compressive strength characteristics are cement characteristics, proportions of aggregates, water/cement ratio, degree of compaction efficiency of curing and temperature during curing period $[7,13]$. The adoption of right curing method for the periwinkle shell concrete may determine how best it can be used in the construction industry.

Some researchers lately have found interest in the use of periwinkle shells in concrete due to its availability especially in the riverine areas. The study of [1] examined the suitability of periwinkle shell as partial replacement for river sand in concrete. They reported that concrete mixes of $0: 1,1: 3,1: 1$ and 1:3 Periwinkle-gravel can be classified as normal weight concrete, while those of $1: 0$ concrete mix of periwinkle-gravel are lightweight concrete.

The study of [2] examined the exploratory study of periwinkle shells as coarse aggregate in concrete works. They observed that $35.4 \%$ and $42.5 \%$ of the periwinkle shell in replacement for granite was quite satisfactory for compressive strength when using concrete mix ratios of $1: 2: 4$ and 1:3:6 respectively. The study of [10] examined the exploratory study of crushed periwinkle shell as partial replacement for fine aggregate in concrete. They found out that $50 \%$ of periwinkle shells can be added to $1: 2: 4$ concrete mix as replacement for fine aggregate to give a compressive strength of $18 \mathrm{~N} / \mathrm{mm}^{2}$ which falls under lightweight concrete according to [3].

The study of [11] evaluated the properties of lightweight concrete using periwinkle shells as a partial replacement for coarse aggregate. He reported that the optimum compressive strength of $16.79 \mathrm{~N} / \mathrm{mm}^{2}$ and $16.71 \mathrm{~N} / \mathrm{mm}^{2}$ at $20 \%$ and $30 \%$ replacement was suitable for lightweight concrete according to ASTM C330 [3]. The study of [9] examined the utilization of periwinkle shells as alternative material to granite chips as coarse aggregate in concrete and concluded that the use of periwinkle shells for concrete would result in low cost housing delivery especially in the riverine areas where they are found as waste. The concrete produced with these periwinkle shells are light weight concretes required for non load bearing walls, non structural floors, strip footing and other non structural elements [6].

Periwinkle shells as partial replacement for crushed granites would go a long way reducing the cost of construction especially in areas where light weight concrete is required. This study tends to unravel the potentiality in periwinkle shell being used as partial replacement for coarse aggregate in concrete and also to ascertain the best curing methods that would be adopted for coastal areas where periwinkle shells are readily available using response surface methodology.

\section{Materials and method}

The material used includes Portland cement, $20 \mathrm{~mm}$ size of crushed coarse aggregate, fine aggregate, periwinkle shell and water. The tools include steel moulds $(100 \mathrm{~mm} \times 100 \mathrm{~mm} \times 100 \mathrm{~mm}$ size), shovel and head pans. The periwinkle shells were washed to remove impurities and dried before usage in the designs mix of $20 \mathrm{~N} / \mathrm{mm}^{2}$ concrete adopted. The periwinkle shells were partially replaced for $5 \%, 10 \%$ and $15 \%$ respectively using 0.5 water/cement ratio. Fifty-six (56) cubes of $100 \mathrm{~mm} \times 100 \mathrm{~mm} \times 100 \mathrm{~mm}$ with two cubes were made for each mix in accordance with [4]. However, the concrete were cast and cured between 7 days and 28 days both in water and air respectively.

Design expert software was used to produce the experimental design for the periwinkle concrete as shown in Table 1. The coded value of $5-15 \%$ for the periwinkle shell and 7-28 days for the curing duration for both air and water curing methods were used. These produced thirteen factorial designs which was performed using grade 20 concrete and the responses were obtained as stated in Table 2.

The regression equations relating the compressive strength of the blended concrete with both the curing durations and percentages of periwinkle ash were developed using a commercial statistical package,

Table 1 Experimental design matrix for the factorial design value for the blended concrete cured with both water and air

\begin{tabular}{lcc}
\hline Experiment & \multicolumn{2}{l}{ Independent variable } \\
\cline { 2 - 3 } & Periwinkle shell (\%) & $\begin{array}{l}\text { Curing } \\
\text { duration } \\
\text { (days) }\end{array}$ \\
\hline 1 & 10 & 18 \\
2 & 10 & 18 \\
3 & 15 & 28 \\
4 & 10 & 5 \\
5 & 5 & 28 \\
6 & 15 & 7 \\
7 & 10 & 28 \\
8 & 15 & 18 \\
9 & 10 & 18 \\
10 & 10 & 18 \\
11 & 5 & 7 \\
12 & 10 & 18 \\
13 & 5 & 18 \\
\hline
\end{tabular}


Table 2 Experimental design matrix for the factorial design and response value for the blended concrete cured with both water and air

\begin{tabular}{|c|c|c|c|c|}
\hline \multirow[t]{2}{*}{ Experiment } & \multicolumn{2}{|c|}{ Independent variable } & \multirow{2}{*}{$\begin{array}{l}\text { Response } 1 \text { (water) } \\
\text { Compressive strength (N/ } \\
\mathrm{mm}^{2} \text { ) }\end{array}$} & \multirow{2}{*}{$\begin{array}{l}\text { Response } 2 \text { (air) } \\
\text { Compressive } \\
\text { strength (N/ } \\
\mathrm{mm}^{2} \text { ) }\end{array}$} \\
\hline & $\begin{array}{l}\text { Periwinkle shell } \\
(\%)\end{array}$ & $\begin{array}{l}\text { Curing duration } \\
\text { (days) }\end{array}$ & & \\
\hline 1 & 10 & 18 & 26.7 & 25.5 \\
\hline 2 & 10 & 18 & 26.7 & 25.5 \\
\hline 3 & 15 & 28 & 27.5 & 22.0 \\
\hline 4 & 10 & 5 & 23.3 & 22.5 \\
\hline 5 & 5 & 28 & 34.8 & 28.5 \\
\hline 6 & 15 & 7 & 19.3 & 13.0 \\
\hline 7 & 10 & 28 & 30.0 & 29.5 \\
\hline 8 & 15 & 18 & 23.0 & 22.0 \\
\hline 9 & 10 & 18 & 26.7 & 25.5 \\
\hline 10 & 10 & 18 & 26.7 & 25.5 \\
\hline 11 & 5 & 7 & 28.0 & 24.5 \\
\hline 12 & 10 & 18 & 26.7 & 25.5 \\
\hline 13 & 5 & 18 & 33.0 & 27.8 \\
\hline
\end{tabular}

Design-Expert Software 7.0.0. (Stat-Ease Inc., Minneapoli, USA). Response Surface Methodology (RSM) using the Central Composite Design (CCD) was applied to study the response (compressive strength of the blended concrete) on the independent variables (curing duration and percentages of periwinkle ash in the concrete). The regression coefficient of the linear model was determined using data obtained from the central composite design employed for the optimization of the independent variables as shown in Eq. (1)

$y=b_{0}+\sum_{i=1}^{n} b_{i} x_{i}+\sum_{i=1}^{n} b_{i i} x_{i}^{2}+\sum_{i i>j}^{n} \sum_{j}^{n} b_{i j} x_{i} x_{j}+e$

where $y=$ predicted response (compressive strength of blended concrete), $b_{0}, b_{i} b_{i j} b_{i j}=$ coefficients, $n=$ number of independent variables, $x_{i}, x_{j}=$ actual factors, $e=$ error term.
$F$ test was used to evaluate the significant of the model while the adequacy of the model was checked using the coefficient of determination $R^{2}$ and adjusted $R^{2}$.

\section{Results and discussion}

Regression equations relating the compressive strength of the blended concrete with both the curing duration and periwinkle shell were developed. The suitability of these equations was tested using the analysis of variance (ANOVA).

Multiple regression analysis was applied on the data in Table 2. The regression analysis was fitted to the polynomial in Eqs. 1-3 were generated in terms of the actual factors for the compressive strengths for both water and air cured blended concrete. ANOVA for the linear model equations were carried out for the blended concrete and the results are presented in Tables 3 and 4

$$
\begin{aligned}
& c S_{w}=29.54422-0.75355 p s_{a}+0.29137 c u_{d} \\
& c s_{a}=26.18757-0.65506 p s_{a}+0.27261 c u_{d}
\end{aligned}
$$

Table 3 Analysis of variance for linear model values of blended concrete cured in water

\begin{tabular}{llllll}
\hline Source & Sum of squares & Degree of freedom & Mean squares & $F$ value & $p$ value prob $>F$ \\
\hline Model & 188.45 & 2 & 94.22 & 118.95 & $<0.0001$ \\
A-periwinkle shell & 113.57 & 1 & 113.57 & 143.38 & $<0.0001$ \\
B-curing duration & 74.88 & 1 & 74.88 & 94.53 & $<0.0001$ \\
Residuals & 7.92 & 10 & 0.79 & & Significant \\
Lack of fit & 7.92 & 6 & 1.32 & 0.000 & \\
Pure error & 0.0 & 4 & & & \\
Cor total & 196.37 & 12 & Pred $\mathrm{R}^{2}=0.9153$ & & \\
$\mathrm{CV}=3.35 \%$ & $\mathrm{R}^{2}=0.9597$ & Adj $\mathrm{R}^{2}=0.9516$ & &
\end{tabular}


Table 4 Analysis of variance for linear model values of blended concrete cured in air

\begin{tabular}{llllll}
\hline Source & Sum of squares & Degree of freedom & Mean squares & $F$ value & $p$ value prob $>F$ \\
\hline Model & 151.37 & 2 & 75.68 & 13.95 & $<0.0013$ \\
A-periwinkle shell ash & 85.82 & 1 & 85.82 & 15.85 & $<0.0026$ \\
B-curing duration & 65.55 & 1 & 65.55 & 12.10 & $<0.0059$ \\
Residuals & 54.16 & 10 & 5.42 & & Significant \\
Lack of fit & 54.16 & 6 & 9.03 & 0.000 & \\
Pure error & 0.000 & 4 & & & \\
Cor total & 205.53 & 12 & Pred $R^{2}=0.4483$ & & \\
CV $=3.35 \%$ & $\mathrm{R}^{2}=0.7365$ & Adj $R^{2}=0.6838$ & &
\end{tabular}

where $c s_{w}=$ compressive strength obtained when cured in water, $c s_{a}=$ compressive strength obtained when cured in air, $p s_{a}=$ periwinkle shell percentage, $c u_{d}=$ curing duration in days.

According to Table 3, the adjusted $R^{2}$ of 0.9516 shows that $95.16 \%$ of the systematic variations in the compressive strength of the concrete is accounted for by the independent variables (periwinkle shell percentage and curing duration). The $F$ value of 118.95 is statistically significant which indicates that the linear model can help us to predict the compressive strength of the concrete when cured in water.

Furthermore, Table 4 shows ANOVA for the linear model of the blended concrete cured in air. The adjusted $R^{2}$ of 0.6838 reveals that $68.38 \%$ of the systematic variations in the compressive strength of the blended concrete are accounted for by the independent variables (periwinkle shell percentage and curing duration). The $F$ value of 13.95 is statistically significant which indicates that the linear model can help us to predict the compressive strength of the concrete when cured in air.

\section{Discussion}

\subsection{Effect of curing duration and periwinkle shell ash percentage on the compressive strength of concrete when cured in water}

The three-dimensional plots of the combined effect of both the age of curing and periwinkle shell percentages on the compressive strength of concrete are shown in Fig. 1. Increasing the age of curing of the concrete, increases the compressive strength. While increasing also the periwinkle shell dosage on the concrete, decreases the compressive strength. When the age of curing of concrete was 28 days at $5 \%$ periwinkle shell dosage, the maximum compressive strength of $34.8 \mathrm{~N} /$ $\mathrm{mm}^{2}$ was attained. This is $74 \%$ increase in compressive strength over the control concrete of $20 \mathrm{~N} / \mathrm{mm}^{2}$. However, maximizing both curing duration and periwinkle shell percentages gave $27.5 \mathrm{~N} / \mathrm{mm}^{2}$ compresive strength for the blended concrete.
Fig. 1 Combined effect of age of curing and periwinkle shell percentage on the compressive strength of the blended concrete cured in water

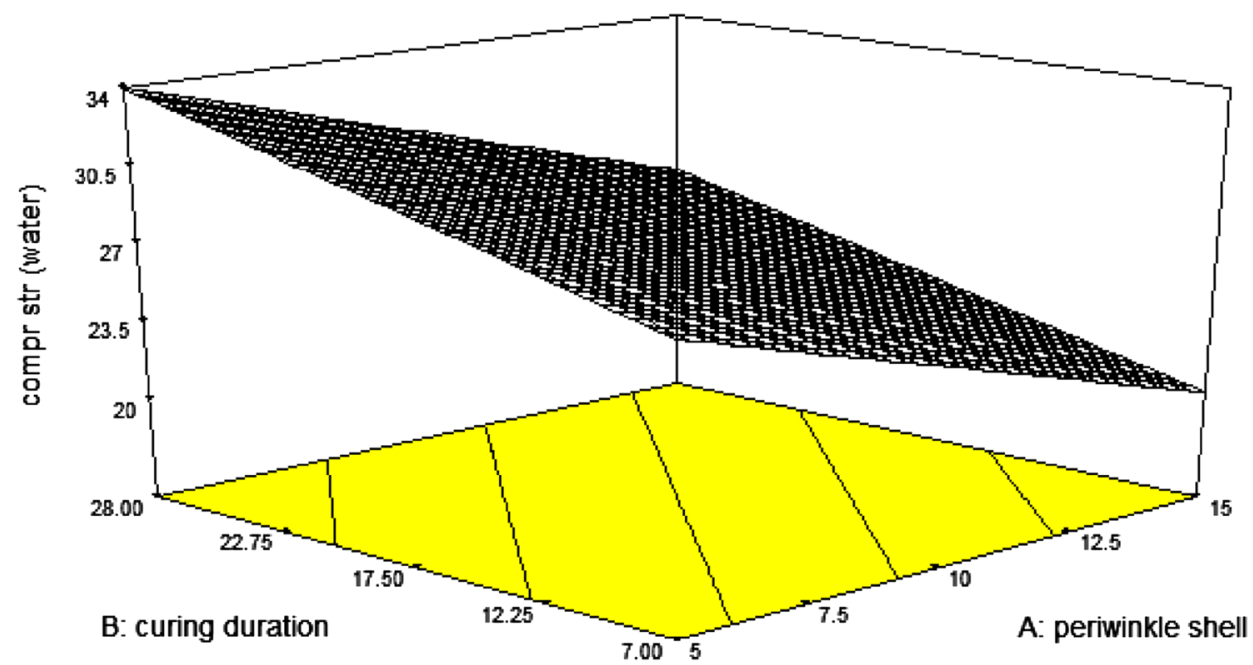


Fig. 2 Combined effect of age of curing and periwinkle shell percentage on the compressive strength of the blended concrete cured in air

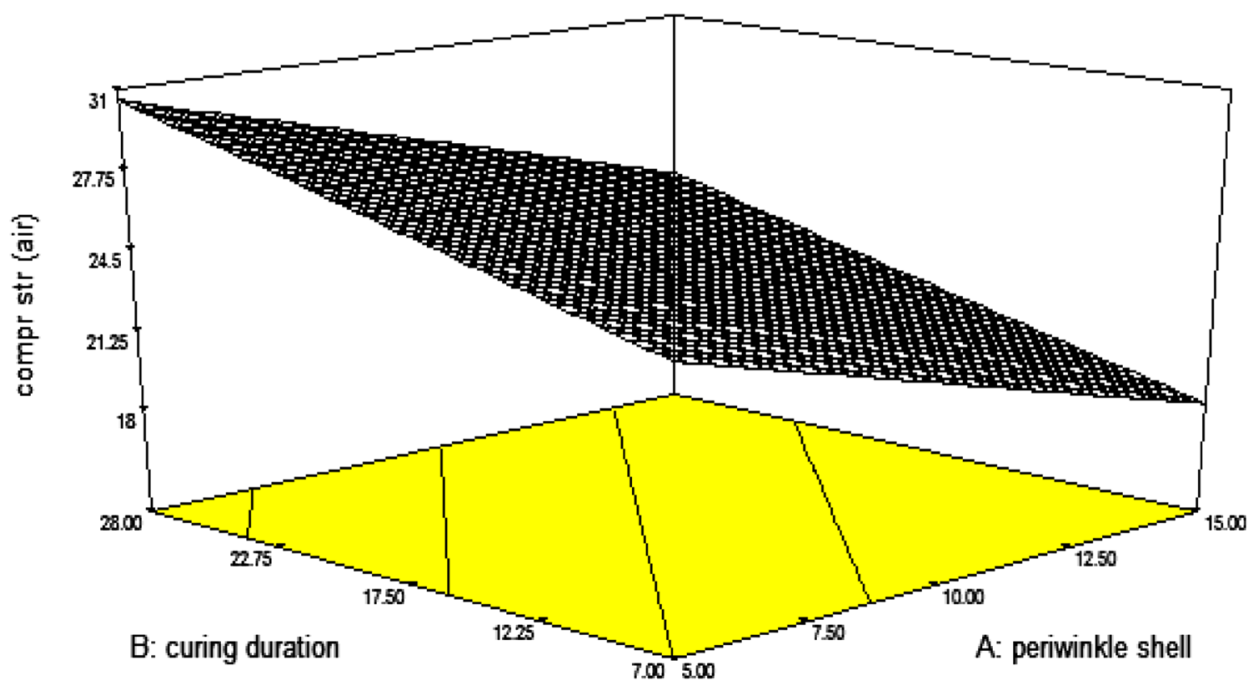

\subsubsection{Effect of curing duration and periwinkle shell percentage on the compressive strength of concrete when cured in air}

The three-dimensional plots of the combined effect of both the age of curing and periwinkle shell percentages on the compressive strength of concrete are shown in Fig. 2. Increasing the age of curing of the concrete, increases the compressive strength. While increasing also the periwinkle dosage on the concrete, decreases the compressive strength. Maximising the compressive strength of the blended concrete and minimizing both periwinkle shell dosage and curing duration gave a compressive strength of $24.5 \mathrm{~N} / \mathrm{mm}^{2}$. The optimum compressive strength of $29.5 \mathrm{~N} / \mathrm{mm}^{2}$ was achieve at $10 \%$ periwinkle shell dosage and 28 days air curing duration. This is $47.5 \%$ increase in compressive strength over the control concrete of $20 \mathrm{~N} /$ $\mathrm{mm}^{2}$.

\section{Conclusion}

It can be concluded from the study that:

1. The blended concrete gained strength with age upon curing irrespective of the curing method adopted.

2. The optimum compressive strength of $29.5 \mathrm{~N} / \mathrm{mm}^{2}$ was achieve at $10 \%$ periwinkle shell dosage and 28 days curing duration when cured in air.

3. When the age of curing of concrete was 28 days at $5 \%$ periwinkle shell dosage, the maximum compressive strength of $34.8 \mathrm{~N} / \mathrm{mm}^{2}$ was attained, when cured in water.

4. Curing method adopted affects the compressive strength of the blended concrete.
5. Water curing is the best curing method when compared to air curing because it increases the compressive strength by $22.1 \%$.

6. The results show that partial replacement with periwinkle shells up to $15 \%$ is possible in concrete since its compressive strength is still above the specified strength of $20 \mathrm{~N} / \mathrm{mm}^{2}$ at 28 days.

7. The Linear model was able to predict the compressive strength of the blended concrete with an adjusted coefficient of determination $\left(R^{2}\right)$ of 0.9516 and 0.6838 for both water and air cured blended concrete.

8. This work has provided a data base for the use of periwinkle shell as partial replacement for coarse aggregate in grade 20 concrete.

\section{Compliance with ethical standards}

Conflict of interest The author declares that he has no conflict of interest.

\section{References}

1. Abede OI, Manasseh J (2009) Suitability of periwinkle shell as a partial replacement for river gravel in concrete. Leonardo Electron J Pract Technol 15:59-66

2. Adewuyi AP, Adegoke T (2008) Exploratory study of periwinkle shells as coarse aggregate in concrete works. Asian Res Publ Netw J Eng Appl Sci 3(6):1-5

3. ASTM C330 (2017) Standard Specification for Lightweight Aggregates for Structural Concrete. In: ASTM international, West Conshohocken. https://doi.org/10.1520/c0330

4. BS 1881, Part 102 (1983)-Testing method for the determination of slump. British Standards Institute, London. https://doi. org/10.3403/00048831u 
5. Dahunsi BIO (2003) Properties of periwinkle-granite concrete. J Civ Eng 8:27-35. https://doi.org/10.4314/jce.v8i1.18993

6. Falade $F$ (1995) An investigation of periwinkle shells as coarse aggregate in concrete. J Build Environ 30(4):573-577. https:// doi.org/10.1016/0360-1323(94)00057-y

7. Neville AM (1993) Properties of concrete, 3rd edn. Longman, London

8. Olafusi OS, Olutoge FA (2012) Strength properties of corn cob ash concrete. J Emerg Trends Eng Appl Sci 3(2):297-301

9. Osayemwen EO (1992) An investigation of the characteristics of lightweight concrete made of periwinkle shells, palm kernel shells, sand and sawdust as aggregates. Unpublished M.Sc. Dissertation. Department of Civil Engineering, University of Lagos, Nigeria

10. Otunyo AW, Friday IU, Isreal TA (2013) Exploratory study of crushed periwinkle shell as partial replacement for fine aggregates in concrete. J Emerg Trends Eng Appl Sci 4(6):823-827
11. Oyedepo OJ (2016) Evaluation of the properties of lightweight concrete using periwinkle shells as a partial replacement for coarse. J Appl Sci Environ Manag 20(3):498-505. https://doi. org/10.4314/jasem.v20i3.2

12. Oyenuga VO (2005) Simplified reinforced concrete design. ASTROS Limited, Lagos

13. Rusinoff A (1998) Composition for preparing the body of concrete: a process for preparing the method of the body of concrete, US. Patent No. 5728428

Publisher's Note Springer Nature remains neutral with regard to jurisdictional claims in published maps and institutional affiliations. 